\title{
Isolation and Identification of Lactic Acid Bacteria from Tempoyak for Making Yoghurt by Morphological and Biochemical Characterization
}

\author{
Hanum Mukti Rahayu ${ }^{1 *}$ \\ ${ }^{1}$ Universitas Muhammadiyah Pontianak, Indonesia \\ hanumunmuhpontianak@gmail.com
}

\begin{abstract}
The selection of starter bacteria in yoghurt fermentation is important to produce yoghurt with good quality. The lactic acid bacteria (LAB) in "tempoyak" (local fermented durian pulp) have the potential to be starter bacteria for making yoghurt because the yoghurt fermentation process is the same as the tempoyak fermentation. This study aimed to isolate and identify morphological and biochemical characterization of LAB from tempoyak which will be used as starter bacteria. LAB selection was based on their ability to produce acid compounds and lactase. LAB isolates were identified based on morphological and biochemical tests. The results of the study obtained 23 isolates of the LAB with the same colony characteristics namely round shape, broken white color with convex elevation and smooth surface, and entire edge. Selection of acid-producing and lactase-producing LAB obtained six isolates (Tp-1, Tp-2, Tp-3, Tp-7, Tp-12, and Tp-19). The biochemical test showed six LABs were gram-positive bacteria, non-endospore, nonmotile, and catalase-negative.
\end{abstract}

\section{Introduction}

Yoghurt is one of the processed drinks resulted from the fermentation process and has a sour taste (Harjiyanti, Pramono, \& Mulyani, 2013). The fermentation process of yoghurt involves the role of lactic acid bacteria (LAB) as starter bacteria. The selection of the right starter bacteria in yoghurt production will determine the taste of the product. Therefore, selecting the right starter bacteria needs to be done to get the taste of yoghurt that is preferred by many people.

One of the local products that have the potential to be starter bacteria in making yoghurt is LAB from tempoyak. Tempoyak is a local food made from fermented durian pulp and is common to Malay communities in Sumatra and Borneo Islands, especially in Bengkulu, Palembang, Lampung, West Sumatra, Jambi, and Kalimantan. Several studies have shown that lactic acid bacteria are the dominant 
microorganism during fermentation (Amin et al., 2006; Maurya et al., 2015) and the fermentation in yoghurt has similarities to the tempoyak fermentation. So this research was aimed to isolate and identify the morphological and biochemical characterization of LAB isolates from tempoyak as the starter candidates on making the yoghurt.

\section{Materials and Methods}

Ripe durian fruit was peeled and separated from seeds. Then about $2 \%$ salt $(\mathrm{b} / \mathrm{b})$ was added to seedless durian meat and they were put in a tightly closed jar to create an anaerobic condition. Jars were left at room temperature for one week. After one week, the jar was opened, and the bacteria were ready to be isolated from tempoyak.

\subsection{Lactic Acid Bacteria Isolation}

One gram of sample was added into $9 \mathrm{ml}$ sterile distilled water and homogenized using the vortex. Serial dilution was performed until the concentration reach $10^{-7}$. One ml of the homogenized and diluted samples were poured into Petri dishes. This culture was incubated at a temperature of $30{ }^{\circ} \mathrm{C}$ for 48 hours. The culture was then purified on MRS media and incubated at a temperature of $30^{\circ} \mathrm{C}$ for 48 hours. The purified culture was stored in MRS agar slant at a temperature of $4-10^{\circ} \mathrm{C}$.

\subsection{Selection of Acid-producing LAB}

To select the lactic acid bacteria (LAB) that have potential on producing acid compound, the selection process using MRS Media $+\mathrm{CaCO}_{3} 0.5 \%$ was conducted. Incubation was done for 68 hours at room temperature $\left(26^{\circ} \mathrm{C}\right)$. The clear zone around the bacteria colony showed that that bacteriaproduced acid. Clear zone measurement was done by determining the bacteria ability on producing acid with clear zone index formula:

$$
\text { Acid clear zone index }=\frac{\text { acid clear zone diameter }}{\text { colony diameter }}
$$

\subsection{Selection of Lactase Producing LAB}

The determination of lactase producer LAB was conducted using TSIA (Triple Sugar Iron Agar) media with the incubation at a temperature of $37^{\circ} \mathrm{C}$ for 24 hours. The culture positively formed protease and lactase marked with the formation of clear zones. Measurement of the clear zone area was done by the formula:

$$
\text { Clear zone index }=\frac{\text { clear zone diameter }}{\text { colony diameter }}
$$

\subsection{Identification of LAB by Morphological and Biochemical Characterization}

The superior isolates were then identified by morphological characterization including shape, color, elevation, surface, and edge. Then, the biochemical characterization has proceeded including gram staining, endospore staining, catalase, and motility test. 


\section{Results and Discussion}

Tempoyak is a traditional food from Indonesia made from fermented durian meat (Durio zibethinus Murray) (Widowati et al., 2013). During the fermentation process, the microorganisms that play a role are dominated by lactic acid bacteria (LAB) (Leisner et al., 2002; Chuah et al., 2016). The $\mathrm{LAB}$ is microorganisms that are widely distributed in various environments that are rich in carbohydrates such as plants, fermented foods, human mucosal surfaces, and inland and sea animals (Florou-Paneri, Panagiota Christaki \& Bonos, 2013). Especially in tempoyak, LAB can grow by fermenting simple sugars from durian meat and turning them into lactic acid and acetic acid (Widowati et al., 2013).

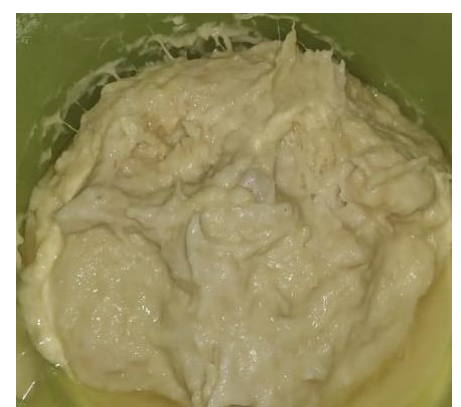

Figure 1: Tempoyak (fermented durian meat)

\subsection{Acid-Producing Lactic Acid Bacteria (LAB) Selection}

Isolation of acid-producing $\mathrm{LAB}$ was carried out on MRSA media with the addition of $\mathrm{CaCO}_{3}$. The isolation results obtained 23 colonies (Tp1-Tp23) with the ability to produce acids. Colonies that have the acid-producing ability are characterized by the formation of clear zones around the colonies in the media (Figure 1). The clear zone shows that LAB can use glucose as the energy source that will produce secondary metabolites in the form of acid. Acidic compounds from LAB can degrade $\mathrm{CaCO}_{3}$ to $\mathrm{Ca}$ lactate which is seen by the formation of clear zones around the LAB colony (Nuryady, Istiqomah, Faizah, \& Ubaidillah, 2014).

\begin{tabular}{cccc}
\hline Isolate & Clear Zone $(\mathbf{c m})$ & Isolate & Clear Zone (cm) \\
\hline Tp-1 & 1.57 & Tp-13 & 1.10 \\
Tp-2 & 1.50 & Tp-14 & 1.00 \\
Tp-3 & 1.22 & Tp-15 & 0.73 \\
Tp-4 & 1.00 & Tp-16 & 0.70 \\
Tp-5 & 0.95 & Tp-17 & 0.70 \\
Tp-6 & 1.00 & Tp-18 & 0.80 \\
Tp-7 & 1.12 & Tp-19 & 1.40 \\
Tp-8 & 1.10 & Tp-20 & 1.00 \\
Tp-9 & 0.80 & Tp-21 & 1.00 \\
Tp-10 & 1.00 & Tp-22 & 1.00 \\
Tp-11 & 0.85 & Tp-23 & 1.00 \\
Tp-12 & 1.27 & & \\
\hline
\end{tabular}

Table 1: Diameter of Clear Zone of Acid-Producing LAB in MRSA + $\mathrm{CaCO}_{3}$ 
The ability to produce acids among 23 strains of lactic acid bacteria is summarized in Table 1 . The isolates with the highest ability produce acids are Tp-1 $(1.57 \mathrm{~cm}), \mathrm{Tp}-2(1.50 \mathrm{~cm}), \mathrm{Tp}-19(1.40$ $\mathrm{cm})$, Tp-12 $(1.27 \mathrm{~cm}), \mathrm{Tp}-3(1.22 \mathrm{~cm})$, and Tp-7 $(1.12 \mathrm{~cm})$, respectively. Based on morphological characters, $23 \mathrm{lab}$ isolates have the characteristics included round colonies, cream-colored with convex elevation, smooth surface, and entire edges (Figure 2). The characteristics of the colony's morphology showed a similarity with the characteristics of lactic acid bacteria in general (Pundir, Rana, Kashyap, \& Kaur, 2013).

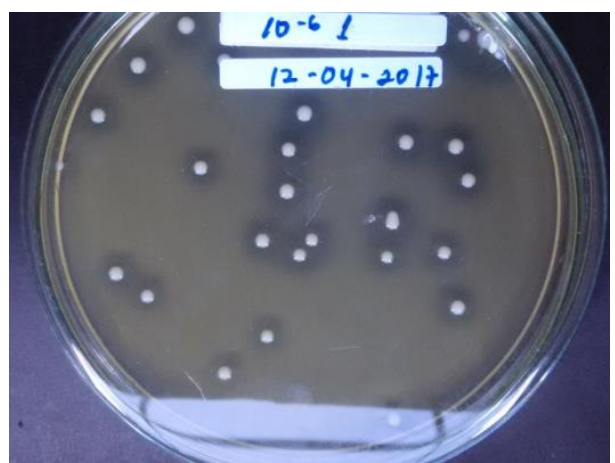

Figure 2: Acid-producing LAB in MRSA + $\mathrm{CaCO} 3$

\subsection{Lactase-Producing Lactic Acid Bacteria (LAB) Selection}

The next stage of the research is screening the best six acid-producing isolates of LAB selected in TSIA media to see the ability of these isolates to produce lactase enzyme. Lactase or $\beta$-Galactosidase is an enzyme known as the biocatalyst to hydrolyze lactose in milk into components of glucose and galactose (Abd El-Kader et al., 2012). Lactase is widely used to prevent the process of lactose crystallization, increase the level of sweetness, and increase the solubility of milk products (Princely et al., 2013). All isolates showed the positive formation of protease and lactase as indicated by the clear zones (Table 2). The highest production of protease and lactase is obtained by Tp-3 $(3.32 \mathrm{~cm})$, meanwhile, the lowest is Tp-19 $(2.12 \mathrm{~cm})$.

\begin{tabular}{cc}
\hline Isolate & Clear Zone (cm) \\
\hline Tp-1 & 2.45 \\
Tp-2 & 3.07 \\
Tp-3 & 3.32 \\
Tp-7 & 2.27 \\
Tp-12 & 3.00 \\
Tp-19 & 2.12 \\
\hline
\end{tabular}

Table 2: Diameter of Clear Zone of LAB on TSIA

\subsection{Identification of Lactic Acid Bacteria (LAB)}

Based on the ability to produce acid and the ability to produce lactase, six superior LAB isolates were obtained namely Tp-1, Tp-2, Tp-3, Tp-7, Tp-12, and Tp-19 isolates. Six lab isolates were identified based on macroscopic and microscopic characters. The macroscopic observations made were the catalase test and the motility test. The catalase test was carried out to identify microbes that can produce the catalase enzyme. The catalase enzyme is used to break down hydrogen peroxide formed 
from aerobic respiration and is toxic to bacteria to become non-toxic dihydrogen oxide and oxygen (Mardalena, 2016). The six isolate catalase test showed negative results because all isolates did not produce bubbles when they were dropped with hydrogen peroxide. One characteristic of LAB is giving negative activity for catalase production (Yuliana et al, 2011; Pundir et al., 2013; Widowati et al., 2013; Chuah et al., 2016; Khalil \& Anwar, 2016). Thus, it can be said that the six isolates were LAB.

Motility is also one of the tests that can be used to differentiate LAB from other bacteria. In the motility test, six isolates were subcultured in a semi-solid upright MRS media and incubated for 48 hours at $30^{\circ} \mathrm{C}$. The test results showed that all isolates were non-motile because the isolates only grew along with the puncture marks. The results of this study are in line with the research of Yuliana et al. (2011), Chuah et al. (2016), and Khalil \& Anwar (2016) who stated that LAB has non-motile characteristics.

As for microscopic observations include observing cell shapes, gram staining, and endospores staining. The results of gram staining showed that the six isolates were gram-positive bacteria because the cells were colored with purple from violet crystals (Figure 3).

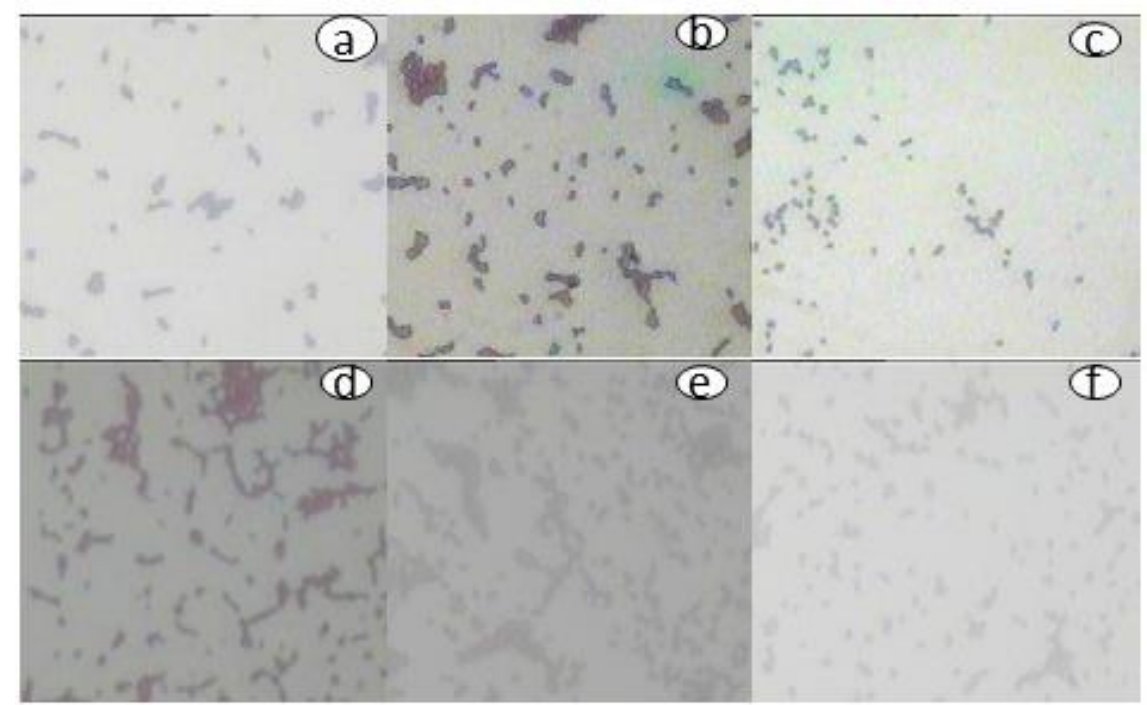

Figure 3: Morphology of (a) Tp-1; (b) Tp-2; (c) Tp-3; (d) Tp-7; (e) Tp-12; (f) Tp-19

Gram staining is used to distinguish between gram-positive and gram-negative bacteria. The purple color in gram-positive bacteria arises because gram-positive bacterial cells have a thick peptidoglycan structure and inner membrane. The peptidoglycan will bind the color of violet crystals and will not fade by ethanol so that the color of gram-positive cells will remain purple (Madigan et al., 2012). According to Leisner et al. (2002), Yuliana et al. (2011), and Widowati et al. (2013), the nature of LAB isolated from tempoyak has gram-positive properties.

The gram staining results also showed that Tp-1, Tp-2, Tp-7, Tp-12, and Tp-19 had the form of rods cells and suspected were Lactobacillus sp. While Tp-3 had a form of coccus so can be suspected as a Streptococcus sp. Lactobacillus is the most dominant bacteria in the tempoyak fermentation process (Leisner et al., 2002; Yuliana et al., 2011; and Widowati et al., 2013; Nuraida, 2015). In this study, endospore staining was also carried out. The test results showed that six isolates (Tp-1, Tp-2, Tp-3, Tp7, $\mathrm{Tp}-12$, and $\mathrm{Tp}-19)$ reacted negatively to endospore staining.

Six superior LAB isolates which could produce acid and lactase were successfully isolated. Identification results show that LAB from tempoyak has gram-positive, non-motile characteristics, no endospores, and a negative catalase reaction. Based on the shape, the LAB has the form of rods and 
coccus cells, which are suspected to be Lactobacillus and Streptococcus, which are the main bacteria that play a role in making yoghurt.

\section{Acknowledgment}

The author thanks LPPM Pontianak Muhammadiyah University for funding this research.

\section{References}

Abubakar, Budi. A dan A. Harsono, 1998. Pengaruh Suhu dan Macam SuhuTerhadap Mutu Yoghurt Selama Penyimpanan. hal 755-760. dalam Prosiding Seminar Nasional Peternakan dan Veteriner. Bogor.

Amin, M.A., J. Zakiah, and Ng.L. Khim. 2004. Effect of salt on tempoyak fermentation and sensory evaluation. Journal of Biology Science, 4: 650-653.

Amin, M.A., J. Zakiah, Ng.L. Khim, and K.W. Lay. 2006. Fermentation of tempoyak using isolated tempoyak culture Research Journal of Microbiology, 1: 243254.

Buchanan, R. E. dan N. E. Gibbon, 1974. Bergey's Manual of DeterminativeBacteriology. Eight edition. The William and Wilkins Company.

Chandan, R. C. dan K. M. Shahani, 1993. Yogurt. In: Dairy Science andTechnologyHandbook. 2. Product Manufacturing. Y. H. Hui, Ed. VCH,Pub., Inc., USA.

Chuah, L-Oon., Syuhada, A.K.S., Liong, M.T., Rosma, A., Thong, K.L., Rusul, G. 2016. Physiochemical, Microbiological Properties of Tempoyak and Molecular Characterisation of Lactid Acid Bacteria Isolated from Tempoyak. Food Microbiology. 58: 95-104.

Florou-Paneri, Panagiota Christaki, E., \& Bonos, E. (2013). Lactic Acid Bacteria as Source of Functional Ingredients. In Lactic Acid Bacteria $-R \& D$ for Food, Health and Livestock Purposes (pp. 589-614).

Harjiyanti, M.D., Pramono, Y.B., dan Mulyani, S. 2013. Total Asam, Viskositas, dan Kesukaan pada Yogurt Drink dengan Sari Buah Mangga (Mangifera indica) sebagai Perisa Alami. Jurnal Aplikasi Teknologi Pangan. Vol. 2 No.2.

Khalil, Md. I dan Anwar, Md. N. 20016. Isolation, Identification and Characterization of Lactic Acid Bacteria from Milk and Yoghurts. Research and Reviews: Jurnal of Food and Dairy Technology. Vol. 4:3.

Leisner, J.J., Vancanneyt, M., Levebvre, K., Vandemeulebroecke, Hoste, B., Vilalta, N. E., Rusul, G., dan Swimgs, J. 2002. Lactobacillus durianis sp. Nov., Isolated from An acid Fermented Condiment (Tempoyak) in Malaysia. International Journal of Systematic and evolutionary Microbiology. Vol. 52:927-931.

Madigan, M., Martinki, J., Stahl, D., dan Clark, D. 2012. Brock Biology of Microorganisms $13^{\text {th }}$ Edition. Pearson education Inc.

Mardalena. 2016. Fase Pertumbuhan Isolat Bakteri Asam Laktat (BAL) Tempoyak Asal Jambi yang Disimpan Pada Suhu Kamar. Jurnal Sain Peternakan Indonesia Vol. 11 No 1 Januari-Juni 2016

Maurya, S., Priya, T., Tripathi, A., Jayanthi, S., and Vimala, R. 2015. Lactic Acid Bacteria: A Potential Tool in Biological Preservation of Food. Research Journal of Pharmaceutical, Biological, and Chemical Sciences. 6(3): 550-555.

Nuraida, L. A Review: Health Promoting Lactic Acid Bacteria in Traditional Indonesian Fermented Foods. Food Science and Human Wellness. Vol. 4: 47-55.

Nuryady. M.M., Istiqomah, T., Faizah, R., Ubaidillah, S., Mahmudi, Z., Sutoyo. Isolasi dan Identifikasi Bakteri Asam Laktat Asal Yoghurt. UNEJ Jurnal. Vol. (1) 5: 1-11. 
Paneri, P. F., Christaki, E., dan Bonos, E. 2013. Lactid Acid Bacteria as Source of Funcional Ingredients. R\&D for Food, Health and Livestock Purposes.

Pundir, R.K., Rana, S., Kashyap, N., dan Kaur, A. 2013, Probiotik Potential of Lactic Acid Bacteria Isolated from Food Samples: An In Vitro Study. Journal of Applied Pharmaceutical Science. Vol. 3 (3): 085-093.

Susilorini, T. E. dan M. E. Sawitri, 2007. Produk Olahan Susu. Penebar Swadaya.Depok. Jawa Barat.

Wahyudi, M. 2006. Proses Pembuatan dan Analisis Mutu Yoghurt. BuletinTeknik Pertanian. Vol. 11 No. 1

Widowati, T.W, Hamzah, B., Wijaya, A., Pambayun, R. 2013. Enumeration and Identification of Dominant Lactic Acid Bacteria in Indonesian "Tempoyak" During Low Temperature Fermentation. Presented on the $13^{\text {th }}$ Asean Food Conference, Singapore.

Widyastuti, Y., Rohmatussolihat, dan Febrisiantosa, A. 2014. The Role of Lactic Acid Bacteria in Milk Fermentation. Food and Nutrition Sciences. Vol. 5: 435-442.

Willey, J.M., Sherwood, L.M., Woolverton, J.C. 2009.Prescott's Principles of Microbiology. McGraw-Hill. New York.

Yuliana, N., Dizon, E.I. 2011. Phenotypic Identification of Lactic Acid Bacteria Isolated from Tempoyak (Fermented Durian) Made in the Philippines. International Journal of Biology. Vo. 3: No.2. 